\title{
PENGUATAN PENDIDIKAN KARAKTER PADA MATA PELAJARAN IPS MATERI TENTANG DINAMIKA KEPENDUDUKAN
}

\author{
Oleh: Kaspul Anwar \\ Email: kaspulanwar85@gmail.com \\ Program Studi Magister Pendidikan IPS \\ Pascasarjana Universitas Lambung Mangkurat Banjarmasin
}

\begin{abstract}
Abstrak
Ilmu Pengetahuan Sosial atau IPS merupakan salah satu mata pelajaran di sekolah tingkat pertama. Salah satu materi di mata pelajaran IPS adalah materi tentang dinamika kependudukan. Materi dinamika kependudukan membahas tentang keadaan penduduk yang ada di muka bumi. Berkaitan dengan dinamika kependudukan, ada beberapa hal yang menjadi perhatian, diantaranya adalah jumlah penduduk, kelahiran, kematian, dan migrasi penduduk. Selain itu, hal lain yang menjadi perhatian lebih khusus adalah terkait interaksi antarpenduduk, baik antarindividu, antardaerah, maupun antarnegara dan antarbangsa. Dalam hal interaksi, bisa terjadi kerja sama maupun konflik. Kerja sama bisa memberi banyak keuntungan, sedangkan konflik bisa sangat merugikan dan membawa banyak permasalahan. Tujuan penelitian ini adalah untuk mendeskripsikan penguatan pendidikan karakter pada mata pelajaran IPS materi tentang dinamika kependudukan. Metode yang digunakan dalam penelitian ini adalah metode kualitatif deskriptif. Data dikumpulkan dengan studi literatur, kemudian dianalisis sesuai tujuan penelitian ini. Hasil dari penelitian ini adalah bahwa pada mata pelajaran IPS materi tentang dinamika kependudukan, saat pembelajaran, guru hendaknya tidak hanya memberi pengetahuan tentang dinamika kependudukan saja, tetapi juga bisa memberi penguatan pendidikan karakter. Penguatan pendidikan karakter tersebut diantaranya dengan mengajarkan ke peserta didik bahwa terkait dinamika kependudukan, kita perlu untuk saling mengenal (bersahabat atau komunikatif), kita perlu untuk saling menciptakan kebersamaan (cinta damai), kita perlu untuk saling memperhatikan (peduli sosial), dan kita perlu untuk saling menghargai (toleransi).
\end{abstract}

Kata kunci: pendidikan karakter, IPS, dinamika kependudukan

\begin{abstract}
Social Science or IPS is one of the subjects in the first level school. One of the materials in social studies lessons is about population dynamics. Population dynamics material discusses the state of the population on earth. In connection with population dynamics, there are several things that are of concern, including population size, births, deaths, and population migration. In addition, another thing that is of more special concern is related to the interaction between people, both between individuals, between regions, as well as between countries and between nations. In terms of interaction, cooperation or conflict can occur. Cooperation can provide many benefits, whereas conflict can be very costly and bring many problems. The purpose of this study was to describe the strengthening of character education in social studies lessons on population dynamics. The method used in this research is descriptive qualitative method. Data were collected with literature studies, then analyzed according to the objectives of this study. The result of this research is that in social studies subject matter about population dynamics, during learning, teachers should not only provide knowledge about population dynamics, but also provide reinforcement of character education. Strengthening character education includes teaching students that related to population dynamics, we need to get to know each other (friendly or communicative), we need to create togetherness (love peace), we need to pay attention to each other (social care), and we need to to respect each other (tolerance).
\end{abstract}

Key words: character education, social studies, population dynamics 


\section{PENDAHULUAN}

Perkembangan zaman semakin hari semakin maju. Ditandai dengan semakin banyaknya ditemukan teknologi-teknologi baru dalam dunia informasi dan komunikasi. Begitu juga dengan perkembangan teknologi transportasi, berkembang dengan sangat pesat. Banyak hal yang sebelumnya tidak ada, sekarang menjadi bagian dari kehidupan kita. Bahkan menjadi sesuatu yang tidak bisa kita hindari. Penggunaan ponsel pintar misalnya, sudah menjadi bagian pokok dari kehidupan kita.

Kemajuan ilmu pengetahuan dan teknologi membawa dampak ke banyak hal, diantaranya kerja sama dan persaingan antarindividu dan antarnegara. Kerja sama membuat orang lebih mudah dalam mengerjakan sesuatu atau mencapai suatu tujuan. Adapun persaingan, ingin merebut sesuatu dengan mengalahkan pihak lain. Terkait persaingan, semua orang dan semua negara saat ini bersaing pada bidangnya masingmasing. Persaingan sangat memungkinkan terjadinya konflik.

Seiring bertambahnya penduduk di bumi, yang jumlahnya sudah mencapai 8 miliar lebih, sedangkan sumber daya alamnya terbatas, sangat rentan menyebabkan tingginya persaingan untuk bertahan hidup. Persaingan tidak hanya antarindividu tetapi juga antarbangsa dan antarnegara. Konflik menjadi sesuatu yang tidak bisa dihindarkan dalam persaingan tersebut (Prasetiyani, 2013).

Saat ini semua negara sedang berlomba ingin menjadi negara yang paling berjaya dalam hal ekonomi dan politik. Perang-perang besar akhir-akhir ini terjadi akibat konflik yang bila ditelusuri ternyata motif ekonomi yang ada di baliknya. Sebut saja beberapa negara yang ada di Timur Tengah, seperti Suriah, Libya dan Afghanistan. Konflik-konflik seperti ini menandakan bahwa di balik keadaan suatu penduduk menyimpan berbagai permasalahan. Ini hanya satu permasalahan. Banyak lagi permasalahan yang lain. Misalnya di negara yang jumlah penduduknya sangat banyak seperti Tiongkok dan India, yang masing-masing negara memiliki jumlah penduduk lebih dari 1 miliar. Kedua negara ini memiliki permasalahan yang tidak sedikit. Dengan pengaruh yang cukup kuat di tingkat dunia saat ini, Tiongkok berusaha agar dia bisa masuk ke negara-negara lain, dari sisi kekuatan ekonomi dan politiknya. Di Indonesia misalnya, banyak terdapat perusahaan yang berasal dari Tiongkok, yang perusahaan tersebut tidak hanya berinvestasi modal, tetapi juga mendatangkan tenaga kerja langsung dari Tiongkok. 
Amerika serikat sebagai negara dengan jumlah penduduk terbanyak nomor tiga di dunia, dengan kekuatan ekonomi dan politiknya juga ingin memberikan pengaruh yang besar ke negara-negara lain. Sebagai negara yang paling berkuasa saat ini, Amerika Serikat ingin agar negara-negara lain tunduk dan patuh kepadanya. Ketundukan dan kepatuhan ini termasuk dalam hal ekonomi dan politik seperti yang diinginkannya. Negara yang tidak patuh, sangat berpotensi untuk dimusuhinya, seperti Korea Utara dan Iran. Keadaan ini sangat memungkinkan terjadinya konflik yang tidak hanya antarbangsa, tetapi juga antar beberapa bangsa.

Persaingan yang tidak sehat menyebabkan konflik. Konflik yang tidak selesai dan terus dibiarkan akan menjadi konflik yang berkepanjangan. Konflik yang berkepanjangan menyebakan rakyat masing-masing negara yang terlibat menjadi sengsara dan dalam ketakukan.

Konflik yang terus berkepanjangan merupakan akibat dari lemahnya pendidikan karakter. Penguatan pendidikan karakter perlu ditanamkan dalam pembelajaran. Termasuk dalam pembelajaran IPS materi dinamika kependudukan. Pendidikan karakter sangat perlu untuk ditanamkan sejak dini. Tujuannya agar lebih dimahami tentang karakter yang baik dan yang buruk. Dengan pemahaman ini, tentu akan menjadi lebih mudah untuk menerapkan karakter-karakter yang baik tersebut. Penanaman karakter yang baik harus ditanamkan dan dibiasakan sejak anak-anak belajar di sekolah.

Pada pembelajaran IPS, materi dinamika kependudukan, saat mempelajari materi dinamika kependudukan, kita disadarkan tentang perlunya memahami berbagai keadaan penduduk beserta permasalahannya. Pemahaman mengenai materi ini menyadarkan kita akan berbagai hal yang banyak terjadi akhir-akhir ini, termasuk diantaranya degradasi atau penurunan penerapan nilai-nilai karakter yang baik di sekitar kita, yang diantaranya karena disebabkan kurangnya pemahaman mengenai pendidikan karaker. Lebih khusus, hendaknya ada penguatan pendidikan karakter pada materi dinamika kependudukan. Berdasarkan permasalahan di atas, sangat perlu dilakukan pemahaman lebih terkait penguatan pendidikan karakter pada mata pelajaran IPS materi tentang dinamika kependudukan. 


\section{METODE}

Metode yang digunakan dalam penelitian ini adalah metode kualitatif deskriptif. Data dikumpulkan dengan studi literatur, kemudian dianalisis sesuai tujuan penelitian. Hasil analisis bertujuan untuk mendapatkan tanggapan atas berbagai permasalahan yang terdapat di bagian pendahuluan.

\section{HASIL DAN PEMBAHASAN}

\section{A. Pendidikan Karakter}

Pendidikan karakter terdiri atas dua kata, yang masing-masing kata memiliki makna mendalam, yaitu kata pendidikan dan karakter. Menurut Kamus Besar Bahasa Indonesia (2008: 352), pendidikan adalah proses pengubahan sikap dan tata laku seseorang atau sekelompok orang dalam usaha mendewasakan manusia melalui pengajaran dan pelatihan. Karakter adalah sifat-sifat kejiwaan, akhlak atau budi pekerti yang membedakan seseorang dengan yang lain.

Pendidikan karakter adalah sebuah sistem yang menanamkan nilai-nilai karakter pada peserta didik yang mengandung komponen-komponen pengetahuan, kesadaran individu, tekad serta adanya kemauan dan tindakan untuk melaksanakan nilai-nilai, baik terhadap Tuhan Yang Maha Esa, diri sendiri, sesama manusia, lingkungan dan juga bangsa, sehingga akan terwujud insan kamil (Nurla Isna Ainullah, 2011: 18).

Menurut Kemendiknas (2011), Pendidikan karakter berkaitan dengan nilai karakter. Nilai karakter berjumlah delapan belas. Sumbernya berasal dari agama, pancasila, budaya dan tujuan pendidikan nasional. Ke depalan belas nilai karakter tersebut adalah (1) Religius, (2) Jujur, (3) Toleransi, (4) Disiplin, (5) Kerja keras, (6) Kreatif, (7) Mandiri, (8) Demokratis, (9) Rasa ingin tahu, (10) Semangat kebangsaan, (11) Cita tanah air, (12) Menghargai prestasi, (13) Bersahabat/komunikatif, (14) Cinta damai, (15) Gemar membaca, (16) Peduli lingkungan, (17) Peduli sosial, dan (18) Tanggung jawab.

\section{B. Dinamika Kependudukan}

Materi kependudukan membahas tentang keadaan penduduk yang ada di permukaan bumi. Secara umum, penduduk di permukaan bumi menempati benuabenua yang ada. Masing-masing benua memiliki penduduk dengan karakteristik 
yang berbeda-beda. Indonesia sebagai negara terbanyak penduduknya nomor empat di dunia memiliki jumlah penduduk sekitar 267 juta, dengan bentuk geografis yang berupa kepulauan, memiliki banyak karakteristik yang berbedabeda di setiap pulaunya. Perbedaan karakter ini menyebabkan perbedaan permasalahan di setiap daerah (Bhagaskara, 2020: 167). Berkaitan dengan dinamikam kependudukan, ada beberapa hal yang menjadi perhatian, diantaranya adalah mengenai jumlah penduduk, kelahiran, kematian, dan migrasi penduduk. Selain itu, hal lain yang menjadi perhatian lebih khusus adalah terkait interaksi antarpenduduk, baik antarindividu, antardaerah, maupun antarnegara dan antarbangsa. Dalam hal interaksi, bisa terjadi kerja sama maupun konflik (Bintarto, 1981).

Terkait kependudukan di Indonesia, kita seakan disuguhkan sebuah keadaan yang cukup memilukan. Bagaimana tidak, akhir-akhir ini kita banyak menemui kesenjangan dalam hal ekonomi, sosial, politik maupun keagamaan. Dalam hal ekonomi yang paling terlihat nyata. Di sekitar jalan raya, banyak terdapat mobil mewah. Di saat yang sama, banyak pengemis yang meminta-minta. Di antara pengemis tersebut, banyak terdapat anak-anak. Keadaan ini menggambarkan bahwa Indonesia sebagai sebuah negara yang jumlah penduduknya sangat besar, memiliki banyak permasalahan terkait kependudukan.

Pembahasan terkait permasalahan kependudukan yang berkaitan dengan kualitas penduduk di Indonesia, di antaranya adalah masalah pendidikan. Pendidikan Indonesia masih sangat rendah. Rendahnya tingkat pendidikan akan berpengaruh terhadap bidang lain seperti lapangan pekerjaan dan pembangunan. Masalah kependudukan lainnya adalah masalah kesehatan. Indonesia tergolong negara dengan tingkat kesehatan disebabkan oleh faktor makanan lingkungan fasilitas kesehatan disebabkan oleh faktor makanan, lingkungan, fasilitas kesehatan dan ketersediaan tenaga medis. Masalah lainnya seperti susahnya mencari lapangan pekerjaan. Harus kita akui, bahwa saat ini sangat susah mencari pekerjaan, apalagi bagi yang memiliki tingkat pendidikan rendah. Padahal pekerjaan sangat berkaitan dengan kebutuhan hidup penduduk secara layak. Ketika kemampuan pemerintah sangat terbatas dan kenyataan bahwa ketersediaan lapangan kerja juga sangat terbatas, maka banyak masyarakat yang kesulitan untuk mencapai keadaan hidup dalam kondisi yang layak. 
Selain jumlah penduduk, Indonesia mengalami pertumbuhan penduduk yang sangat cepat. Untuk mengendalikan laju pertumbuhan penduduk, pemerintah telah mencanangkan program Keluarga Berencana. Tujuannya agar keluarga bisa lebih sejahtera dan diharapkan bisa memenuhi kebutuhan hidup dengan lebih baik. Persebaran penduduk yang tidak merata menjadi permasalahan lainnya. Jumlah penduduk sebagian besar berada di Pulau Jawa. Akibatnya, pembangunan tidak merata. Permasalahan lain terkait kependudukan adalah tingginya mobilitas penduduk. Indonesia sebagai sebuah negara kepulauan, memiliki pergerakan atau mobilitas penduduk yang sangat tinggi. Mobilitas ini ada yang sifatnya harian ada yang sifatnya tahunan. Kalau yang tahunan misalnya saat mudik menjelang lebaran. Kalau yang harian, bisa terlihat dari banyaknya orang yang bekerja ke kota sedangkan dia tinggal di desa.

\section{Pendidikan Karakter dalam Materi Dinamika Kependudukan}

Pendidikan karakter cakupannya sangat luas. Pendidikan karakter tidak lepas dari tujuan utama manusia. Tujuan penting bagi manusia, sebab tanpa tujuan manusia itu seperti kapal yang tidak tahu arahnya kemana. Sebagai orang yang beragama, tentu kita wajib punya tujuan. Tujuan setiap orang yang beragama adalah untuk menjalankan ajaran agama. Tuhan menciptakan manusia untuk beribadah kepadaNya, baik ibadah secara khusus maupun ibadah secara umum. Pendidikan karakter merupakan bagian dari ibadah. Apabila seseorang sudah memiliki pandangan seperti ini, apapun yang seseorang lakukan tujuannya adalah untuk mendekatkan diri kepada Tuhan. Segala perbuatan bertujuan untuk mengingatkan bahwa sebagai hamba harus taat kepada Tuhan. Pendidikan karakter harus bertujuan untuk mendekatkan diri kepada Tuhan, kemudian untuk berbuat lebih baik di kehidupan ini.

Karakter-karakter yang baik perlu dikembangkan agar kita sebagai umat manusia lebih memahami keberadaan kita di muka bumi. Ada tujuan besar selain hanya untuk beribadah kepada Tuhan, yaitu kita juga harus bisa menjadi pemelihara dan orang yang memakmurkan bumi. Kita harus mampu menjaga bumi. Jangan sampai kita berbuat kerusakan di muka bumi, apalagi sampai terjadi konflik atau saling bermusuhan. 
Berkaitan dengan materi dinamika kependudukan, ada banyak sekali nilai-nilai yang bisa dijadikan untuk pendidikan karakter. Beberapa nilai pendidikan karakter dalam materi dinamika kependudukan di antaranya:

\section{Kita perlu untuk saling mengenal (bersahabat atau komunikatif)}

Terkait dengan kita perlu untuk saling mengenal atau bersahabat/komunikatif, hal ini tentu sudah sesuai dengan naluri kita. Kita diciptakan oleh Tuhan dengan keadaan yang berbeda-beda. Setiap penduduk di setiap tempat atau negeri memiliki karakter khas masing-masing. Tempat yang satu dengan tempat yang lain berbeda sehingga penduduknya pun berbeda pula. Perbedaan ini menjadikan kita untuk saling mengenal. Baik cakupannya antarbenua, mapun antarbangsa dan antarnegara. Untuk cakupan yang lebih kecil, misalnya antarsuku dan antarkampung, yang mana kita diharapkan bisa saling mengenal satu sama lain. Bahkan skala lebih kecil lagi, antarrumah atau antartetangga dalam satu komplek, kita harus bisa saling mengenal.

\section{Kita perlu untuk saling menciptakan kebersamaan (cinta damai)}

Terkait dengan kita perlu untuk saling menciptakan kebersamaan atau cinta damai, hal ini sudah menjadi keharusan bagi manusia di manapun berada. Ketika seseorang menempati suatu wilayah, maka ia harus bisa menyesuaikan dengan keadaan di wilayah tersebut. Dia harus bisa berdamai dengan keadaan sekitarnya. Orang yang memahami materi dinamika kependudukan harus bisa memposisikan dirinya supaya mencintai kedamaian dan menghindari konflik. Tujuannya adalah agar tercipta kebersamaan di masyarakat sekitar kita.

\section{Kita perlu untuk saling memperhatikan (peduli sosial)}

Terkait kita perlu untuk saling perhatikan atau peduli sosial, kita harus saling nasehat-menasehati. Nasehat-menasehati ini bisa dilakukan dalam hal kebenaran dan maupun dalam hal kesabaran. Artinya, kita harus peduli ke orang lain, tidak hanya memperhatikan diri kita sendiri. Bila konsep seperti ini diterapkan, maka penduduk di setiap negeri pasti akan selalu dalam keberuntungan, karena masing-masing akan terus menerus saling mengingatkan. 


\section{Kita perlu untuk saling menghargai (toleransi).}

Terkait kita perlu untuk saling menghargai atau bertoleransi, sudah pasti setiap orang harus saling menghargai atau toleransi. Bayangkan apa yang terjadi bila kita tidak saling menghargai atau bertoleransi, maka masing-masing dari kita akan mengambil hak orang lain. Kita harus bertoleransi. Bila suatu penduduk di suatu negeri berbuat toleransi dan saling menghargai seperti ini, maka akan terwujud rasa aman dan damai. Toleransi perlu dimiliki setiap orang dengan cara menjunjung tinggi perbedaan (Abbas, 2017: 37)

\section{Penguatan Pendidikan Karakter}

Nilai-nilai dalam pendidikan karakter harus dikembangkan dan terus diajarkan ke generasi berikutnya. Kalau tidak kita ajarkan ke generasi yang akan datang, maka nilai-nilai tersebut akan berkurang pengamalannya di masa yang akan datang. Sebagaimana yang kita ketahui, tantangan zaman saat ini sudah semakin berat. Di akhir zaman ini, pengaruh teknologi sangat besar dan sangat mudah melunturkan nilai-nilai karakter yang ada di masyarakat kita. Sudah sepatutnyalah bagi kita untuk mempertahankan dan memberikan penguatanpenguatan pada generasi di bawah kita. Bagi orang tua, sudah sepatutnya kita menerapkan nilai-nilai karakter pada anak-anak kita. Bagi guru, hendaknya terus berusaha menerapkan nilai-nilai karakter kepada para murid.

Penguatan pendidikan karakter dalam materi dinamika kependudukan, sudah sepatutnya guru tidak hanya sekedar menjelaskan tentang materi dinamika kependudukan, tapi juga menanamkan karakter-karakter yang harus dimiliki oleh peserta didik terkait materi dinamika kependudukan. Guru harus menanamkan ke siswa bahwa kita perlu untuk saling mengenal (bersahabat atau komunikatif); kita perlu untuk saling menjaga kebersamaan (cinta damai); kita perlu untuk saling memperhatikan (peduli sosial); dan kita perlu untuk saling menghargai (toleransi). Apabila nilai-nilai pendidikan karakter yang baik terus dibangun di masyarakat, maka pasti kehidupan akan menjadi semakin baik. Pasti akan terwujud suatu masyarakat yang harmonis, sejahtera dan lebih bermartabat. Kita perlu meninggalkan generasi yang kuat, sehingga generasi tersebut mampu menghadapi zamannya di masa yang akan datang. Penguatan ini bisa kita lakukan baik di keluarga, masyarakat maupun pemerintah. 


\section{SIMPULAN}

Pendidikan karakter yang merupakan sebuah sistem yang menanamkan nilainilai karakter pada peserta didik, mengandung komponen-komponen pengetahuan, kesadaran individu, tekad serta adanya kemauan dan tindakan untuk melaksanakan nilai-nilai, baik terhadap Tuhan Yang Maha Esa, diri sendiri, sesama manusia, lingkungan.

Terkait materi dinamika kependudukan, yang merupakan bagian dari materi mata pelajaran IPS, banyak membahas tentang keadaan penduduk yang ada di muka bumi. Seiring dengan banyaknya penduduk di dunia, maka berpotensi membawa kepada banyak persoalan. Kita perlu menjadi bijak terkait hal ini, sehingga mampu memunculkan nilai-nilai pendidikan karakter yang baik terkait dengan materi dinamika kependudukan.

Ada beberapa nilai pendidikan karakter yang baik pada materi dinamika kependudukan, diantaranya:

1. Kita perlu untuk saling mengenal (bersahabat atau komunikatif)

2. Kita perlu untuk saling menciptakan kebersamaan (cinta damai)

3. Kita perlu untuk saling memperhatikan (peduli sosial)

4. Kita perlu untuk saling menghargai (toleransi).

Nilai-nilai dalam pendidikan karakter harus dikembangkan dan terus diajarkan ke generasi berikutnya. Baik oleh orang tua, guru maupun setiap individu di dalam masyarakat. Tujuannya agar tercipta keadaaan yang bersahabat atau komunikatif, cinta damai, peduli sosial, dan saling bertoleransi. Apabila nilai-nilai pendidikan karakter ini mengakar kuat di masayarakat dan terus terbangun, maka kehidupan masyarakat pasti akan menjadi lebih baik.

\section{DAFTAR PUSTAKA}

Abbas, E. W. (2015). Guru Sekumpul: Bacaan Pengantar. Penerbit Wahana Jaya Abadi.

Abbas, E. W. (2014). Biografi Propetik Guru Sekumpul (Transformasi Nilai-Nilai Budaya Banjar dalam Pendidikan Karakter).

Abbas, E. W., Subiyakto, B., Mutiani, M., Jamaluddin, J., \& Syahrin, M. A. (2017). Kehidupan Sosial Santri di Bantaran Sungai Kota Martapura Sebagai Sumber 
Belajar IPS. Kehidupan Sosial Santri Di Bantaran Sungai Kota Martapura Sebagai Sumber Belajar IPS.

Ainullah, Nurla Isna. 2011. Panduan Menerapkan Pendidikan Karakter di Sekolah. Yogyakarta: DIVA Press.

Arisanty, D. (2020). Nilai Karakter Pada Materi Geomorfologi. Building Nation Character Through Education.

Bhagaskara, A., Herdiyansyah, M. I., Afandi, M., \& Christie, R. Y. (2020). Kondisi penyerapan tenaga kerja akibat kenaikkan upah minimum. INOVASI, 16(1), 157166.

Bintarto, 1988. Geografi, Ilmu dan Aplikasinya. Majalah Geografi Indonesia. Th. !, No. 2., September 1988. Hal 63-68

Departemen Pendidikan Nasional Indonesia. 2008. Kamus Besar Bahasa Indonesia. Jakarta: Gramedia.

Koesoema, D. (2007). Pendidikan karakter: Strategi mendidik anak di zaman global. Jakarta: grasindo, 212-221.

Prasetiyani, I., \& Widiyanto, D. (2013). Strategi Menghadapi Ketahanan Pangan (Dilihat Dari Kebutuhan Dan Ketersediaan Pangan) Penduduk Indonesia Di Masa Mendatang (Tahun 2015-2040). Jurnal Bumi Indonesia, 2(2). 